\title{
小学生の排便と健康に関する意識調査について
}

\author{
宮川 久邇子, 武 副 礼 子*1, 平 井和 子*1, \\ 村 井 陽 子*2, 長谷川 ちゆ子*3, 岡 本 佳 子*4 \\ 武庫川女子大学, ${ }^{* 1}$ 大阪市立大学, ${ }^{* 2}$ 三先小学校, ${ }^{* 3}$ 西脇小学校, ${ }^{* 4}$ 神戸女学院大学
}

\section{Bowel Movements of Elementary School Children}

\author{
Kuniko Miyagawa, Reiko Takezoe*1, Kazuko Hirai*1, Youko Murai*2, Chiyuko Hasegawa*3 and Keiko Okamoto*4 \\ Mukogawa Women's University, ${ }^{* 1}$ Osaka City University, ${ }^{* 2}$ Misaki Elementary School, \\ ${ }^{* 3}$ Nishiwaki Elementary School, ${ }^{* 4}$ Kobe College
}

A questionnaire study was conducted among elementary school children (aged 9 to 11 years old ; 610 boys and 630 girls) concerning their bowel movements and awareness. If they had bowel movements of less than three times a week, they were considered to be suffering from constipation.

1) There were more number of girls $(18 \%)$ than boys $(15 \%)$ who were suffering from constipation. Conversely, more boys $(41 \%)$ had regular bowel movements every day than girls $(29 \%)$ showing a significant difference by $\operatorname{sex}(p<0.001)$.

2) When asked about dietary habits, $83 \%$ of boys and $85 \%$ of girls answered that their dietary life was suitable for maintaining health. Those who agreed that "constipation and health were correlated" numbered $53 \%$ of boys and $55 \%$ of girls. As for the frequency of defecation, $39 \%$ each of boys and girls answered they should have regular bowel movements every day, while $44 \%$ of boys and $45 \%$ of girls answered that the regularity did not matter. This tendency was more notable among children with constipation tendency or irregular bowel movements $(p<0.01)$.

3) There was no sex difference for the frequency of skipping meals. Fifteen $\%$ of both boys and girls skipped breakfast. Those with less number of bowel movements skipped meals more $(p<0.05)$.

4) As for children who complained of abdominal pain, $69 \%$ of boys and $83 \%$ of girls indicated that they had abdominal pains. The time for bowel movement was not definite for $57 \%$ of boys and $65 \%$ of girls, between the time they arose in the morning and breakfast for the next largest group. A correlation was found between the time of defecation and the degree of constipation $(p<0.01)$.

Jpn. J. Nutr., 47 ( 5 ) 233 240 (1989)

\section{緒言}

近年，食生活が欧米型となり，栄養状態の改善がみられ，特に児童の体位の向上に顕著に現れている。他方， 児童の肥満や高脂血症等の小児性成人病の増加が問題となり，摂取栄養素のアンバランスが示唆されている1)。 また小学生の場合に, 野菜, 海藻類の攝取量と, 食欲不振, 疲労感, 便秘等の全身的自覚症状の訴えとの関連 性が報告されており ${ }^{2)}$, 児童の偏食を防ぐための栄養教育が必要であると思われる。野菜, 海藻類等に多く含 まれている食物繊維と多くの慢性疾患との関連性がいわれ ${ }^{3,4)}$, 特に食物緎維は排便促進に作用し5)，糞便の通

Key words : bowel movements, bowel habits, awareness of the importance of bowel movements 排便傾向，排便状況，排便への意識 
過時間を短縮させて発癌性物質と組織との接触時間を短くする等, 大腸癌に対する予防的役割があるといわれ ている ${ }^{6.7)}$ 。これらのことより，子どもの頃から便通を改善することは健康保持に重要であると考えられる ${ }^{8}$ が, 若年層の排便状況と排便に対する意識についての資料はほとんど得られていない。著者らは, 排便傾向と食生 活に関する調査の一環として, 女子大生とその両親の排便傾向について調査 (9)を行ったところ, 学生の排便回 数が両親よりも少ない結果を得, 若年層での排便頻度の減少が示唆された。そこで, 小学生の排便状況の実態 を把握し，さらにそれらの実態と排便に関する意識との関連性を検討した。

\section{調 査 方 法}

調查対象者は, 大都市として大阪市内の小学 3,4 年生 (男子 466 人, 女子 471 人), 中都市として兵庫県 内の小学 3,4 年生（男子 144 人, 女子 159 人）の計男子 610 人, 女子 630 人について, 昭和 61 年11月下旬に 養護教諭および学校栄養士の指導のもとに調査を行った。なお, 排便回数が 1 週間に 3 回以下の場合を便秘と みなし, 毎日排便がある場合（ 1 週間に 7 回以上）と, その中間值（ 1 週間に $4 \sim 6$ 回）とに区分して比較し た。また，クロス集計に対する検定には $\chi^{2}$ 検定を用いた。

\section{調 查 結 果}

\section{1. 小学生の排便傾向}

小学生の排便回数を表 1 に示したが, 全体から判断すると, 排便回数が週に 3 回以下の便秘がちの児童は男 女平均 $17 \%$, 週に 4 〜 回の排便の児童は $49 \%$, 毎日排便のある児童は $35 \%$ あった。居住地域により排便回 数に有意な差はみられなかったが, 男女ともに大阪よりも兵庫のほうが便秘の児童が多い傾向がみられた。男 女別に比較すると， 1 週間に 3 回以下の排便の児童は男子の $15 \%$ に対して女子は $18 \%$ と多く，逆に毎日排便の ある児童は男子の $41 \%$ に対して女子は $29 \%$ と少なく, 排便回数に性差がみられた $(p<0.001)$ 。特に大阪で は男子に比べ女子の排便回数が少なかった $(p<0.001)$ 。

\section{2. 食生活や排便に関する意識と排便傾向との関連性}

健康を保つのに適した食生活を“している”・“だいたいしている”と答えた割合は男子 $83 \%$ ，女子 $85 \%$ と

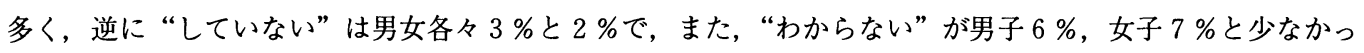
た（表 2.a)。すなわち, 食生活に対する意識に性差はみられなかったが, 自分の食生活について, $83 \%$ 上

表 1 小学生の排便傾向 排便回数 (/週)

\begin{tabular}{|c|c|c|c|c|c|c|c|}
\hline & & & \multicolumn{4}{|c|}{ 排便回数（/週） } & \multirow{2}{*}{$\begin{array}{c}\text { 男女間の関連性 } \\
\left(\chi^{2} \text { 検定 }\right)\end{array}$} \\
\hline & & & $\sim 3$ & $4 \sim 6$ & $7 \sim$ & $\chi^{2}$ 検定 & \\
\hline 全体 & 平 & 均 & $206(16.6)^{*}$ & $603(48.6)$ & $431(34.8)$ & & \\
\hline \multirow{3}{*}{ 男子 } & 大 & 阪 & $65(13.9)$ & $209(44.9)$ & $192(41.2)$ & & \multirow{6}{*}{$p<0.001$} \\
\hline & 兵 & 庫 & $26(18.1)$ & $60(41.7)$ & $58(40.3)$ & ns & \\
\hline & 平 & 均 & $91(14.9)$ & $269(44.1)$ & $250(41.0)$ & & \\
\hline \multirow{3}{*}{ 女子 } & 大 & 阪 & $84(17.8)$ & $258(54.8)$ & $129(27.4)$ & \multirow{3}{*}{ ns } & \\
\hline & 兵 & 庫 & $31(19.5)$ & $76(47.8)$ & $52(32.7)$ & & \\
\hline & & 均 & $115(18.3)$ & $334(53.0)$ & $181(28.7)$ & & \\
\hline
\end{tabular}

*（）内の数值は\% 


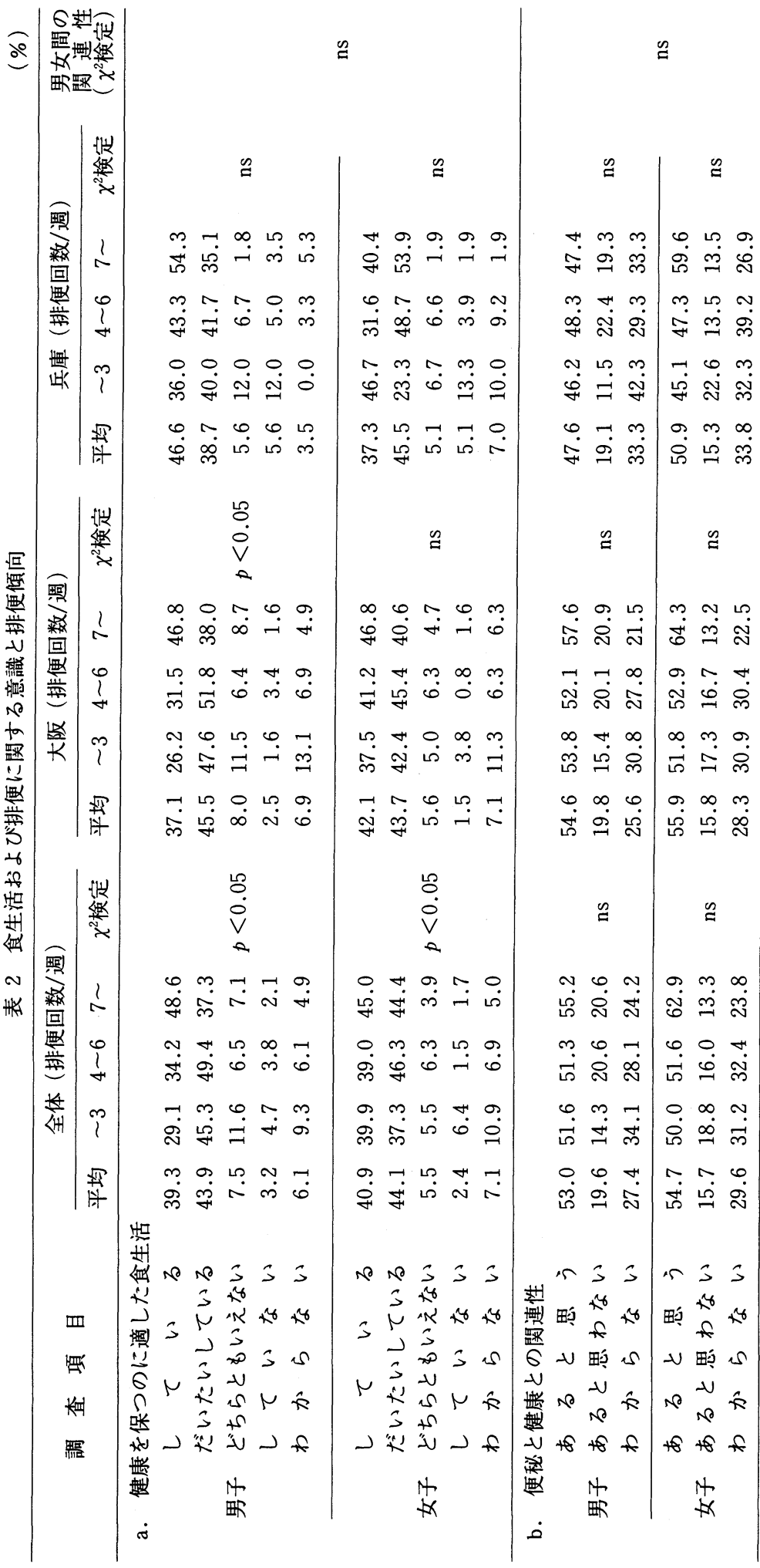

?

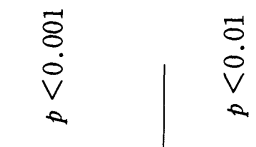

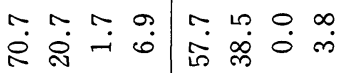
$m-1 m \infty$ ஸึ่

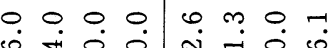

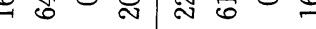

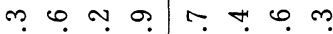

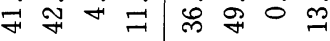<smiles>[Si]=[Ca]</smiles>
5
8
0
0

เ ํ.

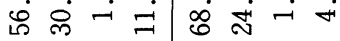
๓ $\backsim+\infty \quad$ o $\infty$ \% ล เ $\sim \neg$ m

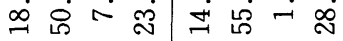
$\because$ เ

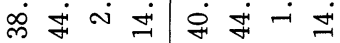
$\sigma$
0
0
0 0
0
0

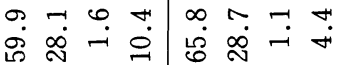
$\forall \sim$ 几 ஸे เूं $\infty \forall \sigma N$ เ ㄷำ เั กิ $\infty$ ᄀ

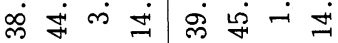

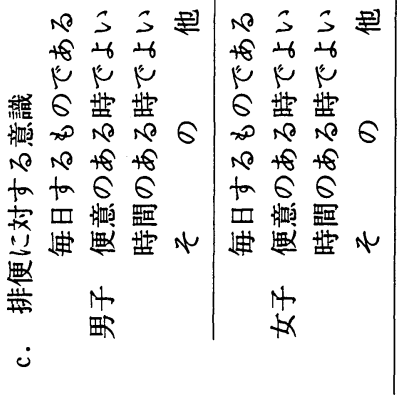




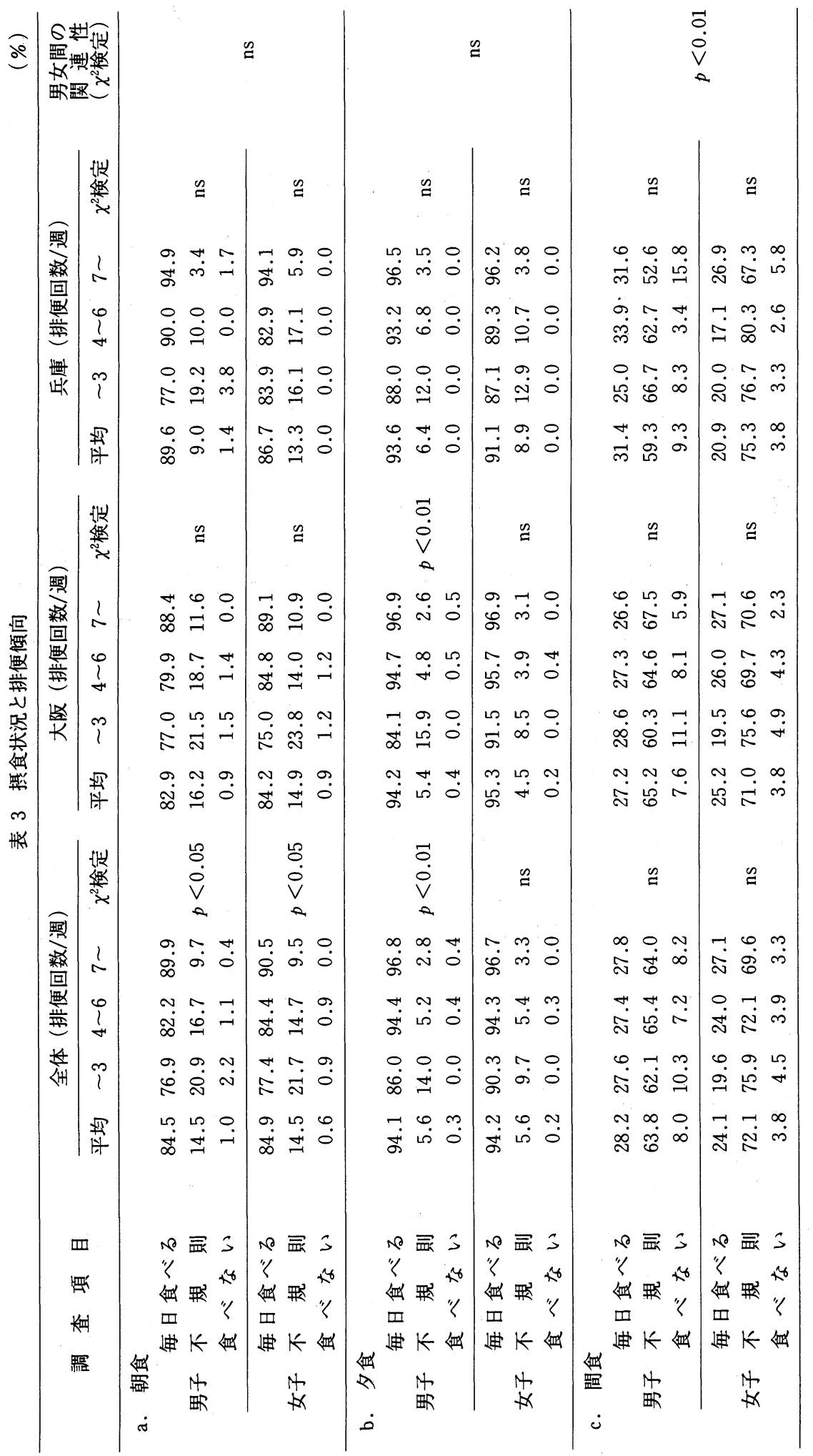




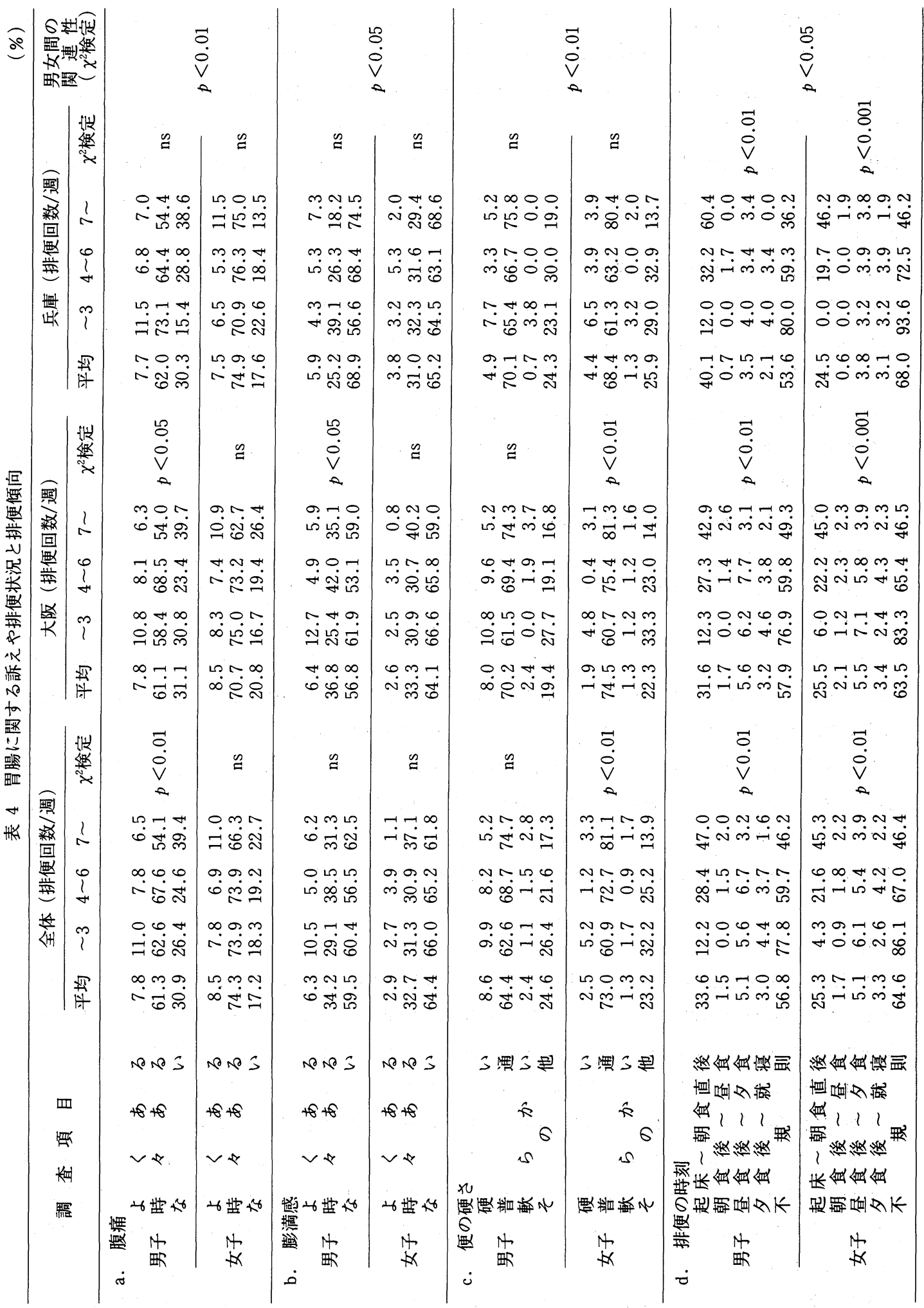


の児童が健康保持に自信があるのに対し, 疑問を有する児童は少なかった。しかしながら便秘の児童には前者 が少なく後者が多く，食生活に対する意識と排便回数に関連性がみられた（男女とも， $p<0.05) 。$

便秘に対する認識を比べると，便秘と健康に関連性があると思っている児童は男子 $53 \% ， 女 子 55 \%$ 低く， “わからない”は各々 $27 \%, 30 \%$ と多く，男女とも両地域において排便の重要性の認識が低かった（表 $2 . b) 。$ 排便については, “毎时るもの”と答えたのは男女とも $39 \%$ と低く, 男子の $44 \%$ と女子の $45 \%$ が “便意のあ る時でよい”と答え, 特に便秘の児童の場合にその傾向が男女とも顕著であった（表 $2 . c$; 男女とも, $p<$ 0.01 )。

\section{3. 摄食状況と排便傾向との関連性}

表 3 に示したように, 朝食の摂取状況に地域差や性差はみられず, 全体平均で毎日朝食を摂取する览童は男 女とも $85 \%$ であり, 久食者は $15 \%$ であった。また男女ともに便秘の児童に欠食率が高く, 排便回数の多い児童 に欠食率が低く，朝食欠食状況と排便回数に関連性がみられた（男女とも， $p<0.05 ） 。$ 夕食を毎日は摂取し ない割合は男女とも $6 \%$ みられ，特に男子では排便回数の少ない児童に欠食率が高かった $(p<0.01)$ 。間

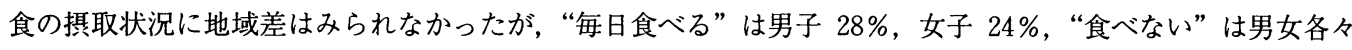
$8 \%$ と 4 であった。

\section{4. 胃腸に関する訴えや排便状況と排便傾向との関連性}

胃腸に関する訴えについては表 4 に示したように, “腹痛”があるのは男子 $69 \%$ に対し女子 $83 \%$ と女子に多 く, 特に男子では排便が少ない場合に腹痛を訴える児童が多かった $(p<0.01)$ 。“腹部の膨満感”があると答 えたのは男子 $41 \%$ ，女子 $36 \%$ で，男女ともに整腸の必要性が示唆された。便の硬さを比べると，男子の $9 \%$ が硬い便で, 女子 $(3 \%)$ より多く, 普通便も女子の $73 \% に$ 対して男子は $64 \%$ と少なく, 性差がみられた $(p<0.01)$ 。便の状態と排便回数に男子では関連性がみられなかったが，女子では便秘の児童に硬い便の割合 が多く逆に普通便が少なく，排便回数と便の状態に関連性がみられた $(p<0.01)$ 。

排便時刻に居住地域差はみられなかったが，排便の時刻は男女とも不規則が最も多く，特に女子では $65 \%$ と 男子 (57\%) より多かった（表 4.d)。次に起床から朝食直後の排便が多く, 男子 $34 \%$, 女子 $25 \%$ で, 排便 時刻に性差がみられた $(p<0.05)$ 。排便傾向と排便時刻を比べると, 男女ともに便秘の児童ほど起床から朝 食直後の排便が少なく不規則が多く，排便回数と排便時刻に関連性がみられた（男女とも， $p<0.01 ） 。$

\section{考察}

本報告の児童の排便回数は，週に 3 回以下の便秘がちの児童は男女平均 $17 \%$, 毎日排便のある児童は $35 \%$ であったが, 阿部 ${ }^{10)}$ の報告（小学 5 年生：毎日排便 $58 \% ， 1$ 週間に 3 回以下の排便 $10 \%$ ）と比べて本報告の 児童のほうが毎日排便の割合が少なく，1 週間に 3 回以下の児童が多かった。このように $65 \%$ 小学生に毎 日排便がないことや，便秘がちの児童が女子大学生 $(16 \%)^{9)}$ と同程度に多いことから判断すると，若年層で の排便回数は年齢とは直接関係なく，排便回数に影響する他の因子が示唆された。若年層での排便回数の減少 の一因として，小学生の野菜や豆嫌い(10) とそれらの摂取不足が考えられる。野菜や豆は，海藻，きのこ類と同 様に繊維含量が多く8), 排便促進に作用する ${ }^{5)}$ こや, 小学生の野菜類の摂取量が全身的自覚症状 ${ }^{2}$ や身体的健 康度 ${ }^{111}$ と相関することが報告されていることからも, 海藻, きのこ類と合わせ, 野菜の摂取を指導する必要が あると思われる。

排便回数について男女別に比較すると，男子よりも女子のほうが排便回数が少なく，性差がみられた。この 
結果は他の地域の小学生 ${ }^{10)}$ の調査とも一致し, 成人 ${ }^{9)}$ の場合と同様に男性よりも女性に便秘率が高い傾向が小 学生の頃より生じていることが明らかとなった。また小学生の場合に, 食欲不振や疲労感等と同様に便秘が全 身的自覚症状の訴えに多かったことが報告されており ${ }^{2)}$, 心身の健康な発達のために毎日の排便を指導するこ とが大切であると思われる。

健康を保つのに適している食事を摂取していると答えた割合が男女とも $83 \%$ 以上と多いことや，食生活に対 する意識と排便回数に関連性がみられたことから判断すると, 男女ともに健康について関心をもっていること が推察された。さらに, 健康保持のための食生活を指導することによって, 児童の食生活の改善が期待され, ひいては排便回数の改善にも役立つものと思われる。また, 便秘と健康に関連性があると思っている児童が男 女とも $55 \%$ 以下と低いことや, 毎日の排便を意識していない児童が $61 \%$ 以上と多かったことは, 排便と健康 との関連性を認識していない児童が多いことを示し, 児童の健全な発育と健康増進のための手段として排便の 重要性を教育し, 積極的に排便に努めるように指導することが必要であると思われる。

毎日朝食を摂取する児童は男女とも $85 \%$ で, 奈良 $(95 \%)^{12)}$, 東京 $(92 \%)^{13)}$, 徳島 $(93 \%)^{14)}$ の小学生に比 べて朝食摂食率が低く，間食の摂取（男子 $28 \%$, 女子 $24 \%$ ）も，奈良 $(43 \%)^{12)}$ や東京 $(31 \%)^{13)}$ の小学生と 比べて少ない傾向がみられた。また朝食欠食状況と排便回数に関連性がみられ，このことからも欠食をしない ように指導することが栄養素の摄取不足, 偏食の防止とともに排便回数の改善に役立つものと思われる。食生

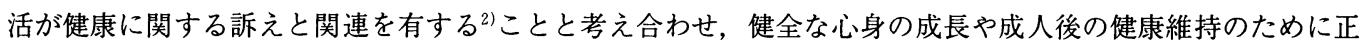
しい栄養指導・教育が若年層より必要であると思われる。

腹痛は子どもの場合に病気の症状として頻度が高く, 排便で消失するものの他に多くの疾患から発現すると いわれている ${ }^{15)}$ 。本調査でも “腹痛” が男子 $69 \%$, 女子 $83 \%$ と中学生 (男女各々 $\left.52 \%, 64 \%\right)^{16)}$ よりも多く, 排便の改善とともに腹痛の原因を解明し，適切な治療の必要性が示唆された。便の硬さを比べると，女子では 便秘の児童に硬い便の割合が多く, 排便回数と便の硬さに関連性がみられたが, 女子中学生 ${ }^{16)}$, 女子大学生や 母親9の場合に排便回数の減少に伴い硬便の比率の増加がみられたことから判断すると，女性の場合には児童 の頃よりそのような傾向が生じることが示唆され，特に女子の場合に早い時期より排便の改善に努めるように 指導することが重要であると思われる。

男女ともに排便の時刻の不規則が多かったが, 東京 ${ }^{13}$ の小学生の場合にも朝の排便が $34 \%$ に対し不規則が $50 \%$ と多く, 排便時刻が一定でない小学生が多いことが認められた。また徳島の小学生 ${ }^{14)}$ では, 毎朝の排便者 が全体平均で $40 \%$ であのに対し，女子が $29 \%$ と少なく，本調査結果と同様な傾向が報告されている。成人 の場合と同様に, 排便傾向と排便時刻に関連性がみられ, 成人の場合にも便秘の場合に排便が不規則となるこ と采から判断して, 小学生の不規則な排便が成人よりも多かったことは, 小学生の便秘が今後増加することを 示唆していると思われる。健康のために便秘をなくし，規則正しい排便の習慣をつけるためには，排便時刻を 規則正しくすることが重要であると思われる。

\section{要 約}

小学 3,4 年生 (大阪市内の男子 466 人 - 女子 471 人, 兵庫県内の男子 144 人 ·女子 159 人, 合計男子 610 人・女子 630 人）を対象に，排便傾向と排便に関する意識についてアンケート調査を行った。なお，排便回数 が週に 3 回以下のものを便秘とみなして集計した。

1）便秘の小学生は男子（15\%）より女子（18\%）に多く，逆に毎日排便のある児童は男子 (41\%) のほう 
が女子 $(29 \%)$ よりも多く，排便に男女差がみられた（ $p<0.001 ） 。$

2）健康を保つのに適した食生活を“している”・“だいたいしている”と答えた割合は男子 $83 \%$ ，女子 85\%で, “便秘と健康に関連性がある”は男子 $53 \%$, 女子 $55 \%$ あっあた。排便頻度については, “毎日寸るも

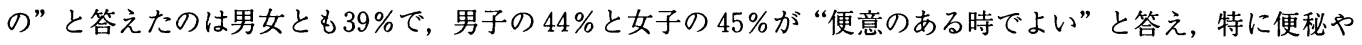
不規則な児童の場合にその傾向が顕著であった $(p<0.01)$ 。

3） 欠食頻度については性差はみられず, 朝食の欠食率は男女とも $15 \%$ で, 排便回数の少ない児童ほど欠食 率は高かった。

4）腹痛のある児童は男子 $69 \%$, 女子 $83 \%$ あっった。排便時刻は不規則が最も多く, 男子 $57 \%$, 女子 $65 \%$ で, 次に起床から朝食直後であった。排便回数の少ない児童ほど起床から朝食直後の排便率が低く, 便秘 の児童では排便時刻も不規則が多かった $(p<0.01)$ 。

本調査を行うにあたり, 多大なご助力を賜りました調查対象校の養護教諭および学校栄養士をはじめ諸先生 方に深謝いたします。

なお本調查の一部は第34回日本栄養改善学会において発表した。

文

献

1)：味方陽子, 梅原佳代子, 川村貴子, 坂本好美, 三ツ沢明葉, 坂田貴美子, 酒匂美津恵, 中山月瀬, 前里 恭子, 福川美和子, 菊池ふみ子, 寿円梅子, 㴊上達夫, 大国真彦, 梁 茂雄, 杉山光男, 横川岩根, 稀 代幸雄，山内邦昭：小児保健研究，44，565 572（1985）

2）鈴木雅子, 羽原富江：学校保健研究, 23，169１73 (1981)

3）厚生省保健医療局健康増進栄養課：栄養日本，31，319～321（1988）

4）印南：敏，桐山修八編：食物絨維, pp.271 334（1985）第一出版

5）印南 敏：食の科学, 94, 37〜50 (1985)

6) Burkitt, D. P., Walker, A. R. P. and Painter, N. S. : Lancet, 30, 1408 1411 (1972)

7) MacLennan, R., Jensen, O. M., Mosbech, J. and Vuori, H. : Am. J. Clin. Nutr., 31, S239 S242(1978)

8）名尾良憲：便秘一その成り立ちから治療まで（1980）ライフ・サイエンス

9）武副礼子, 平井和子, 許 淑珍, 田附ツル, 岡本佳子, 川上塋子, 宮川久邇子：栄盖学雑誌, 44, 111 １18 (1986)

10）阿部裕吉：学校の食事, 13，24４8（1980）

11）垣本 充, 三戸秀樹：栄養学雑誌, 34, 199 205（1976）

12）米山京子：小児保健研究， 45，339 344（1986）

13）増田陽三：小児保健研究，44，604～610（1985）

14）松浦弘子, 伊東秀子, 上田房子：四国女子大学研究紀要, 27, 39 51（1980）

15）柿沢至恕, 河合 洋, 中條俊夫, 山口規容子：小児の腹痛（1987）医歯薬出版

16）平井和子, 武副礼子, 家崎幹雄, 岡本佳子, 堀田(原)久子, 宮川久邇子：生活衛生, 32, 121 126 (1988)

（受付：昭和63年11月 7 日） 